\title{
IODP Expedition 322 Drills Two Sites to Document Inputs to The Nankai Trough Subduction Zone
}

\author{
by Michael B. Underwood, Saneatsu Saito, Yu'suke Kubo, and \\ the IODP Expedition 322 Scientists
}

doi: 10.2204/iodp.sd.10.02.2010

\begin{abstract}
The primary goals during Expedition 322 of the Integrated Ocean Drilling Program were to sample and log the incoming sedimentary strata and uppermost igneous basement of the Shikoku Basin, seaward of the Nankai Trough (southwestern Japan). Characterization of these subduction inputs is one piece of the overall science plan for the Nankai Trough Seismogenic Zone Experiment. Before we can assess how various material properties evolve down the dip of the plate interface, and potentially change the fault's behavior from stable sliding to seismogenic slip, we must determine the initial pre-subduction conditions. Two sites were drilled seaward of the trench to demonstrate how facies character and sedimentation rates responded to bathymetric architecture. Site C0011 is located on the northwest flank of a prominent basement high (Kashinosaki Knoll), and Site
\end{abstract}

C0012 is located near the crest of the seamount. Even though significant gaps remain in the coring record, and attempts to recover wireline $\operatorname{logs}$ at Site $\mathrm{C} 0012$ failed, correlations can be made between stratigraphic units at the two sites. Sedimentation rates slowed down throughout the condensed section above the basement high, but the seafloor relief was never high enough during the basin's evolution to prevent the accumulation of sandy turbidites near the crest of the seamount. We discovered a new stratigraphic unit, the middle Shikoku Basin facies, which is typified by late Miocene volcaniclastic turbidites. The sediment-basalt contact was recovered intact at Site $\mathrm{C} 0012$, giving a minimum basement age of 18.9 Ma. Samples of interstitial water show a familiar freshening trend with depth at Site C0011, but chlorinity values at Site $\mathrm{C} 0012$ increase above the values for seawater toward the basement contact. The geochemical trends at Site C0012 are probably a response to hydration reactions in the volcaniclastic sediment and diffusional

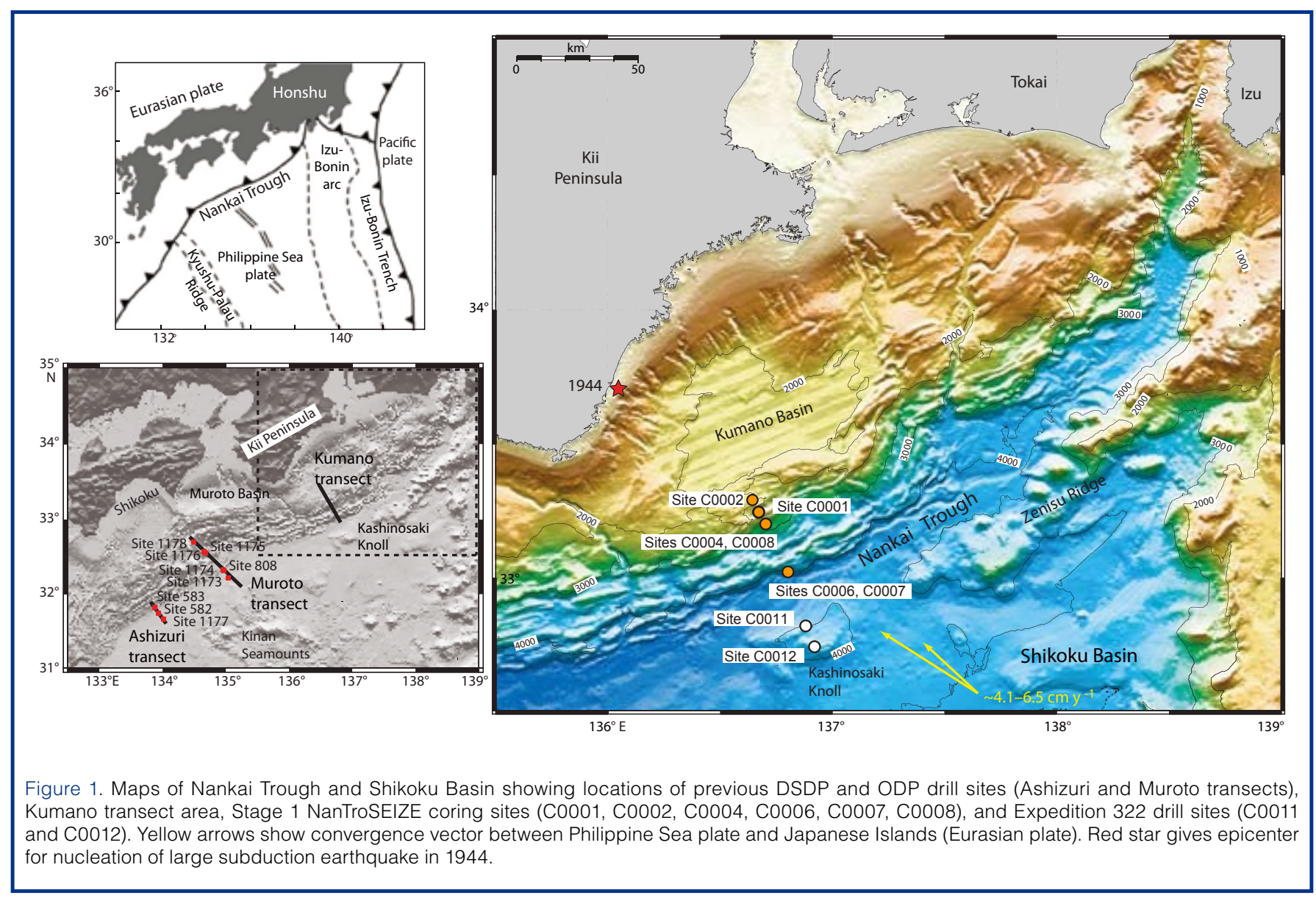


exchange with seawater-like fluid in the upper igneous basement. These data are important because they finally establish an authentic geochemical reference site for Nankai Trough, unaffected by dehydration reactions, and they provide evidence for active fluid flow within the upper igneous crust. Having two sets of geochemical profiles also shows a lack of hydrogeological connectivity between the flank and the crest of the Kashinosaki Knoll.

\section{Introduction and Goals}

Subduction megathrusts are responsible for some of the world's deadliest earthquakes and tsunamis. To improve our understanding of these hazards, an ambitious project known as the Nankai Trough Seismogenic Zone Experiment (NanTroSEIZE) was initiated along the subduction boundary of southwestern Japan, with the overarching goal of creating a distributed observatory spanning the up-dip limit of seismogenic and tsunamigenic behavior (Tobin and Kinoshita, 2006a, 2006b). Using an array of boreholes across the Kumano transect area (Fig. 1), scientists hope to monitor in situ conditions near a major out-of-sequence thrust (megasplay) and the subduction megathrust (plate interface). This multi-stage project is in the process of documenting several key components of the subduction margin, starting with the pre-subduction inputs of sediment and oceanic basement (Underwood et al., 2009), moving landward into the shallow plate interface (Tobin et al., 2009), and finally drilling to depths of 6-7 km where earthquakes occur.

Expedition 322 of the Integrated Ocean Drilling Program (IODP) was organized to sample and log incoming sedimentary strata and igneous basement of the Shikoku Basin, prior to their arrival and burial at the Nankai subduction front (Saito et al., 2009). It is only through such sampling that we can pinpoint how various geologic properties and diagenetic transformations (e.g., clay composition, cementation, microfabric, fluid production, pore pressure, friction, thermal state) change in 3-D space and through time. When viewed in the broader context of NanTroSEIZE, it is particularly important to understand pre-subduction conditions, because the down-dip evolution of those initial properties is what ultimately changes slip behavior along the plate interface from aseismic to seismic (Vrolijk, 1990; Hyndman et al., 1997; Moore and Saffer, 2001). Drilling was therefore conducted at two sites seaward of the trench (Fig. 1). Site C0011 is located on the northwest flank of a prominent bathymetric high (the Kashinosaki Knoll), whereas Site C0012 is located near the crest of the seamount.

\section{Geological Setting and Earlier Work}

The Shikoku Basin formed as part of the Philippine Sea plate during the early to middle Miocene by rifting and seafloor spreading along the backarc side of the Izu-Bonin volcanic chain (Okino et al., 1994; Kobayashi et al., 1995). Prominent basement highs within the Shikoku Basin include the Kinan seamount chain (Fig. 1), which grew along the axis of the extinct backarc spreading center, and isolated seamounts such as the Kashinosaki Knoll (Ike et al., 2008a). The subducting plate is currently moving toward the northwest beneath the Eurasian plate at a rate of $\sim 4$ to $6 \mathrm{~cm}$ $\mathrm{yr}^{-1}$ (Seno et al., 1993; Miyazaki and Heki, 2001), roughly orthogonal to the axis of the Nankai Trough. Shikoku Basin deposits, together with the overlying Quaternary trench wedge, are actively accreting at the deformation front, as demonstrated within the Kumano transect area by IODP Expeditions 314, 315, and 316 (Tobin et al., 2009).

As summarized by Underwood (2007), our knowledge of inputs to the Nankai subduction zone is rooted in pioneering drilling discoveries from the Muroto and Ashizuri transects (Deep Sea Drilling Project [DSDP] Legs 31 and 87 and Ocean Drilling Program [ODP] Legs 131, 190, and 196) (Karig et al., 1975; Kagami et al., 1986; Taira et al., 1991; Moore et al., 2001a; Mikada et al., 2002). Those studies demonstrated, among other things, that the plate-boundary fault (décollement) propagates through Miocene strata of the lower Shikoku Basin facies, at least near the toe of the accretionary prism (Taira et al., 1992; Moore et al., 2001b). One of the primary objectives of NanTroSEIZE is to track physical/chemical changes down the plate interface from shallow depths toward seismogenic depths, so the highest-priority sampling targets lie within the lower Shikoku Basin.

Seismic reflection data from across the width of the Shikoku Basin reveal a large amount of heterogeneity in terms of acoustic character and stratigraphic thickness (Ike et al., 2008a, 2008b). Seafloor relief was created during construction of the underlying igneous basement, and that relief strongly influenced the basin's early depositional history (Moore et al., 2001b; Underwood, 2007). As an example of such influence, elevation of the seafloor along the Kinan seamount chain inhibited transport and deposition of sand by gravity flows, so Miocene-Pliocene sediments above the extinct ridge consist almost entirely of hemipelagic mudstone. In contrast, coeval Miocene strata on the flanks of the Kinan basement high consist largely of sand-rich turbidites (Moore et al., 2001b). There are also important differences across the width of the basin (from SW to NE) in values of heat flow, clay mineral assemblages, and the progress of clay-mineral diagenesis (Yamano et al., 2003; Underwood, 2007; Saffer et al., 2008).

Within the Kumano transect area (Fig. 1), seismic reflection data show that the décollement is hosted by lower Shikoku Basin strata to a distance of at least 25-35 km landward of the trench (Moore et al., 2009). Farther landward, the plate-boundary fault steps down section to a position at or near the interface between sedimentary rock and igneous basement (Park et al., 2002). To learn more about the stratigraphic architecture of the Shikoku Basin, Expedition 322 drilled Site C0012 at the crest of Kashinosaki Knoll and Site 


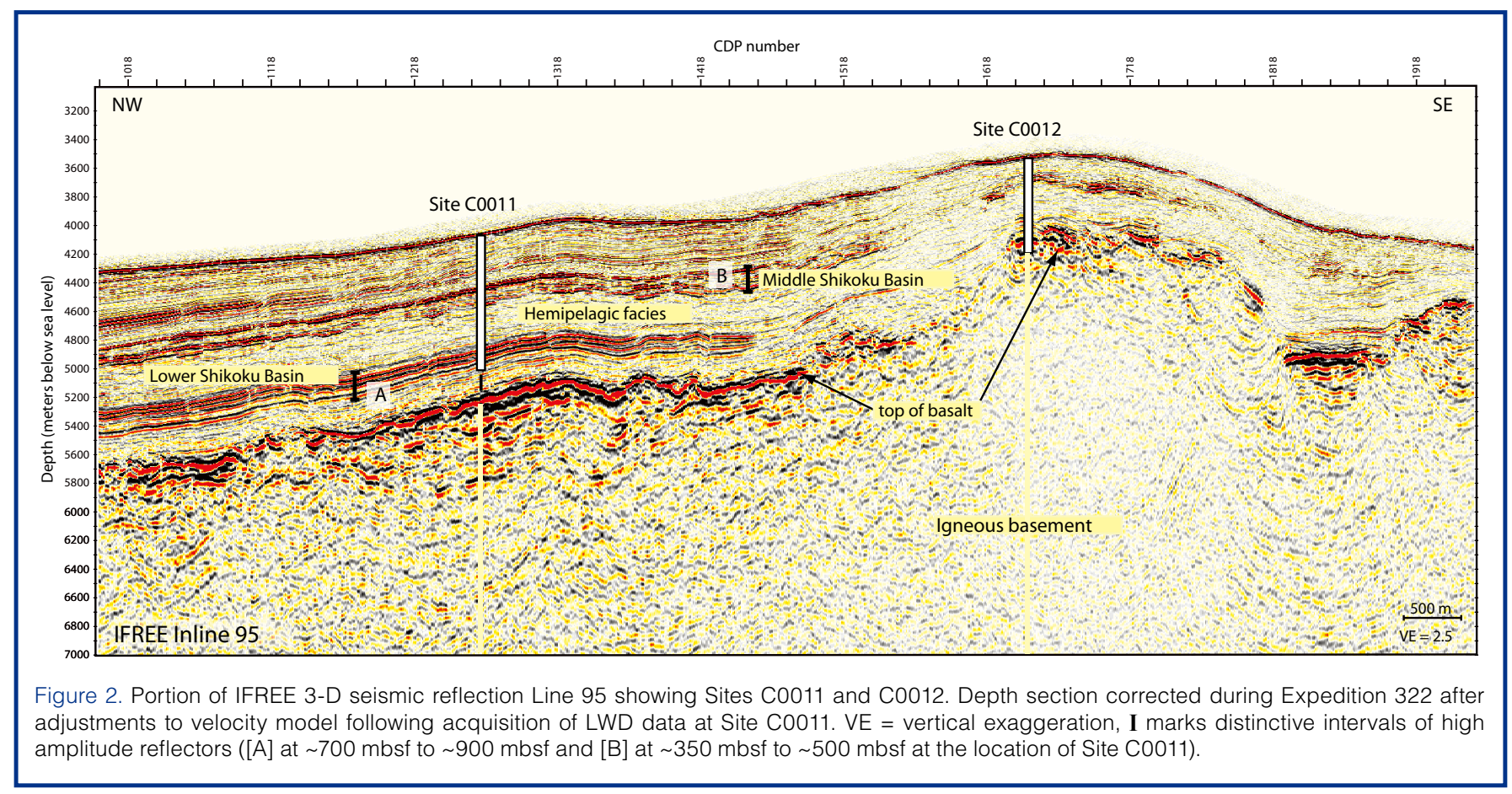

C0011 along its northwest flank (Fig. 2). In the vicinity of Site C0011, seismic profiles include two particularly distinctive intervals of high-amplitude reflectors: the first from $\sim 350$ meters below seafloor (mbsf) to $\sim 500 \mathrm{mbsf}$ and a second with better lateral continuity of reflectors beginning at $~ 700 \mathrm{mbsf}$ (Fig. 2). Both of these packets of reflectors change thickness but can be traced up and over the crest of Kashinosaki Knoll. These particular depth intervals, plus the sediment-basalt interface, represented the primary coring targets for the expedition (Saito et al., 2009).

\section{Principal Results from Site C0011}

Near the end of Expedition 319, measurement-while-drilling and logging-while-drilling (LWD) data were collected at Hole C0011A (Saffer et al., 2009). Generally, we were able to make confident correlations between the logs and subsequent data from rotary core barrel $(\mathrm{RCB})$ cores, with a vertical offset of $\sim 4 \mathrm{~m}$ between the coring hole and the logging hole. Five logging units were defined on the basis of visual inspection of the gamma ray and ring resistivity responses (Underwood et al., 2009). These subdivisions also correlate reasonably well with the seismic stratigraphy. For example, the two intervals with high amplitude reflectors (Fig. 2) match up with $\log$ responses that are indicative of sand (stone) and volcanic ash/tuff beds. Structural analysis of the borehole resistivity images showed that bedding dips $<20^{\circ}$ toward the north, which is consistent with the relatively gentle dip observed in the seismic profiles down the landward-facing slope of Kashinosaki Knoll. Analysis of borehole breakouts indicates that the maximum horizontal stress field (SHmax) is orientated north-northeast to south-southwest, roughly perpendicular to the convergence direction of the Philippine Sea plate.
Because of contingency time restrictions (including anticipation of time lost for typhoon evacuations), coring at Hole C0011B began at $340 \mathrm{mbsf}$ rather than the mudline (Fig. 3). Lithologic Unit I was not cored, so its character is inferred from LWD data (Underwood et al., 2009) and by analogy with the upper part of the Shikoku Basin at ODP Sites 808, 1173, 1174, and 1177 (Taira et al., 1992; Moore et al., 2001b). The dominant lithology of this upper Shikoku Basin facies is hemipelagic mud (silty clay to clayey silt) with thin interbeds of volcanic ash (mostly air-fall tephra). Below $340 \mathrm{mbsf}$, we used biostratigraphic data to merge certain parts of the magnetic polarity interval with the geomagnetic polar-ity reversal time-scale; this resulted in an integrated age-depth model that extends from $\sim 7.6 \mathrm{Ma}$ to $\sim 14.0 \mathrm{Ma}$ (Fig. 4). The composite model yields average rates of sedimentation (uncorrected for either compaction or rapid event deposition by gravity flows) ranging from $4.0 \mathrm{~cm} \mathrm{k.y.}{ }^{-1}$ to $9.5 \mathrm{~cm} \mathrm{k.y.}{ }^{-1}$.

Lithologic Unit II is late Miocene ( 7.6-9.1 Ma) in age and extends in depth from 340 to 479 mbsf (Fig. 3). We named this unit the middle Shikoku Basin facies; it consists of moder-ately lithified bioturbated silty claystone with interbeds of tuffaceous sandstone, volcaniclastic sandstone, dark gray clayey siltstone without appreciable bioturbation (mud turbidites), and a chaotic interval of intermixed volcaniclastic sandstone and bioturbated silty claystone (mass transport deposit). Channel-like sand-body geometry is evident in both LWD data and seismic character. The volcanic-rich sandstones contain mixtures of primary eruptive products (e.g., fresh volcanic glass shards) and reworked fragments of pyroclastic and sedimentary deposits. The closest volcanic terrain at the time was probably the Izu-Bonin arc, located along the northeast margin of the Shikoku Basin (Taylor, 1992; Cambray et al., 1995); we interpret Izu-Bonin to be the 
main sediment source for SW-directed, channelized turbidity currents. No such deposits are known to exist within the western half of the Shikoku Basin.

Lithologic Unit III is middle to late Miocene ( 9.1- 12.2 Ma) in age and extends from $479 \mathrm{mbsf}$ to $674 \mathrm{mbsf}$ (Fig. 3). Its dominant lithology is bioturbated silty claystone, typical of the hemipelagic deposits throughout the Shikoku Basin. Secondary lithologies include sporadic dark gray silty claystone, lime mudstone, and very thin beds of ochre calcareous claystone. The most unusual aspect of this unit is the deceleration in the rate of hemipelagic sedimentation at $\sim 10.8 \mathrm{Ma}$ (Fig. 4).

Unit IV is middle Miocene $(\sim 12.2-14.0 \mathrm{Ma})$ in age and extends from $674 \mathrm{mbsf}$ to 850 mbsf (Fig. 3). Core recovery within this interval was particularly poor, and our interpretations were further hampered by poor core quality and the decision to wash down without coring from $782 \mathrm{mbsf}$ to 844 mbsf. The dominant litho$\operatorname{logy}$ is bioturbated silty claystone with abundant interbeds of dark gray clayey siltstone (deposited by muddy turbidity currents) and fine-grained siliciclastic sandstone (deposited by sandy turbidity currents). We suggest that the most likely terrigenous sources for this sandy detritus were rock units now exposed across the Outer Zone of southwest Japan, including the Shimanto Belt (Taira et al., 1989; Nakajima, 1997). Superficially similar sand deposits, with overlapping ages, have been documented on the southwest side of the Shikoku Basin at ODP Site 1177 and DSDP Site 297 offshore the Ashizuri Peninsula of Shikoku (Marsaglia et al., 1992; Fergusson, 2003; Underwood and Fergusson, 2005).

The age of Unit $\mathrm{V}$ is poorly constrained within the range of middle Miocene ( 14.0 Ma). It extends from $850 \mathrm{mbsf}$ to $876 \mathrm{mbsf}$, but our ability to characterize these strata was

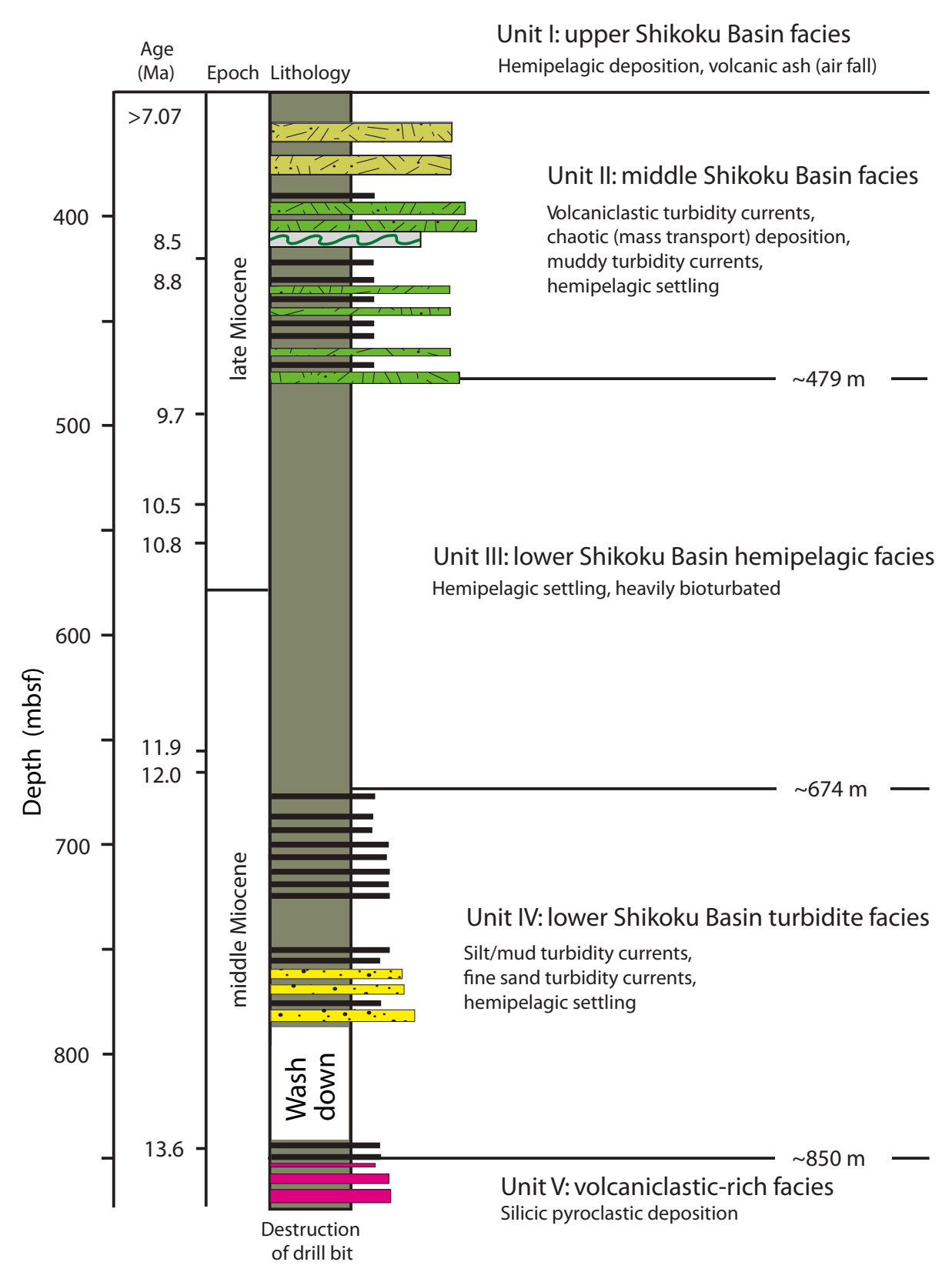

Igneous basement
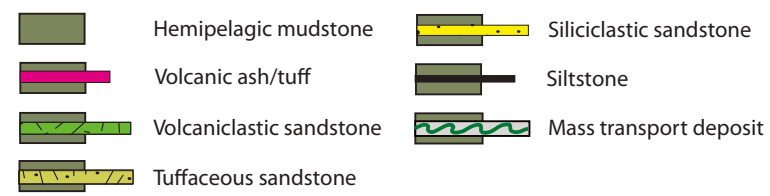

Figure 3. Lithologic units and depositional ages from nannofossils data Hole C0011B.

prevented by poor core recovery. In fact, the unit's lower boundary coin-cides with destruction of the drill bit, which forced us to abandon the hole. The dominant lithologies are tuffaceous silty claystone and light gray tuff with minor occurrences of tuffaceous sandy siltstone. X-ray diffraction data show an abundance of smectite and zeolites within this unit as alteration products of volcanic glass. These deposits probably correlate with the thick rhyolitic tuffs at ODP Site 808 (Muroto transect of the Nankai Trough), which yielded an age of $13.6 \mathrm{Ma}$ (Taira et al., 1991). 
Structural features at Site C0011 include sub-horizontal to gently dipping bedding planes and small faults. Synsedimentary creep and layer-parallel faults developed in Units II and III, whereas a high-angle normal fault/fracture system is pervasive in Units IV and V. Deformation-fluid interactions were also deduced from mineral-filled veins precipitated along faults. Poles to these structures are distributed along a north-northwest to south-southeast trend, perpendicular to the present trench axis, and the orientations correlate nicely with the LWD-based measurements.

Although the data are adversely affected by widespread damage to cores, physical properties show downhole increases in bulk density and decreases in porosity indicative of sediment consolidation. These trends coincide with increases in P-wave velocity and electrical resistivity. The velocity-porosity relation is consistent with previous observations from Shikoku Basin sediments (Hoffman and Tobin, 2004). Velocity anisotropy changes from isotropic to anisotropic (i.e., horizontal velocity faster than vertical velocity) near $440 \mathrm{mbsf}$, which we attribute to compaction-induced alignment of mineral grains. We also detected a shift in magnetic susceptibility near 575 mbsf, which correlates with the change in sedimentation rate at 10.8 Ma (Fig. 4).

Good quality samples were difficult to collect for interstitial water analysis because of persistent core disturbance and low water content. Contamination by seawater (drilling fluid) is evident in all data profiles, and corrections had to be made on the basis of sulfide concentrations. The top of the sampled sediment section (340 mbsf) lies beneath the sulfate-methane interface; thus, we have no information on shallow processes associated with organic carbon diagenesis. Chlorinity in the sampled fluids decreases from $\sim 560 \mathrm{mM}$ to $\sim 510 \mathrm{mM}$, which is $\sim 9 \%$ less than the typical value of $558 \mathrm{mM}$ for seawater (Fig. 5). This freshening trend is superficially consistent with the pattern observed at ODP Site 1177, Ashizuri transect of the Nankai Trough (Moore et al., 2001a). Judging from the similarity of chlorinity profiles, we tentatively suggest that the sampled fluids were altered at greater depths by clay dehydration reactions. If this interpretation is correct, then fluid migration toward Site C0011from zones of diagenesis in the frontal accretionary prism and/or beneath the trench wedge-probably occurred along permeable conduits of turbidite sandstone. The lack of borehole temperature measurements at Site C0011 hinders a more definitive interpretation (i.e., in situ dehydration versus deeper seated dehydration). The distributions of major and minor cations document extensive alteration of volcanogenic sediments and oceanic basement, including the formation of zeolites and smectite-group clay minerals. These reactions lead to consumption of silica, potassium, and magnesium and the production of calcium. The very high calcium concentrations $(>50 \mathrm{mM})$ favor authigenic carbonate formation, even at alkalinity of $<2 \mathrm{mM}$. 
In spite of the sediment's low content of organic carbon (average $0.31 \pm 0.17 \mathrm{wt} \%$ ), the dissolved hydrocarbon gas concentrations in interstitial water increase with depth. Methane is present as a dis-solved phase in all samples. Ethane was detected in all but one core taken from depths $>422 \mathrm{mbsf}$. Dissolved propane was first observed at $568 \mathrm{mbsf}$ and is present in almost all deeper cores. Butane occurs sporadically below $678 \mathrm{mbsf}$. The widespread occurrence of ethane results in low $\mathrm{C} 1 / \mathrm{C} 2$ ratios $(\sim 277 \pm 75)$, which are unusual for sediments with organic carbon contents of $<0.5 \mathrm{wt} \%$. Without better con-straints on temperature at depth, it is difficult to resolve the potential contributions of heavier hydrocarbons from in situ production versus a deeper/hotter source coupled with up-dip migration along sandy intervals with higher permeability.

\section{Principal Results from Site C0012}

Attempts to acquire wireline logs failed at Site C0012, so our results are based on RCB coring. During the RCB jet-in, lithologic Unit I (upper Shikoku Basin facies) was not cored between $0.81 \mathrm{mbsf}$ and $60 \mathrm{mbsf}$. The unit extends from the seafloor to $\sim 151$ mbsf, below which we recovered the first volcaniclastic sandstone of middle Shikoku Basin facies (Fig. 6). The dominant lithology of Unit I is green-gray intensely bioturbated silty clay(stone), and thin layers of volcanic ash are scattered throughout. Modest amounts of biogenic calcite are compatible with hemipelagic settling on top of Kashinosaki Knoll at a water depth close to (but above) the calcite compensation depth. The integrated age-depth model (Fig. 7) places the lower boundary of Unit I at $\sim 7.8 \mathrm{Ma}$ and shows sedimentation rates decelerating from $4.3 \mathrm{~cm} \mathrm{k.y.}{ }^{-1}$ to $1.2 \mathrm{~cm} \mathrm{k.y.}{ }^{-1}$ at $~ 7.1 \mathrm{Ma}$.

Lithologic Unit II (middle Shikoku Basin facies) is late Miocene (7.8 $\mathrm{Ma}$ to $\sim 9.4 \mathrm{Ma}$ ) in age and extends from 151 mbsf to 220 mbsf (Fig. 6). The dominant lithology recovered is green-gray silty claystone, alternating with mediumto thick-bedded tuffaceous/volcaniclastic sandstone and dark gray clayey siltstone. Unit II also contains two chaotic deposits with disaggregated pieces of volcanic-rich sandstone and mudstone that show folding, thinning, and attenuation of primary bedd-ing, probably deformed by gravitational sliding on the north-facing slope of the Kashinosaki Knoll. The volcanic sandstones were not expected at the top of the knoll, and they probably shared a common Izu-Bonin source with Unit II at Site C0011. Their existence seemingly requires upslope transfer by turbidity currents (Muck and Underwood, 1990) and/or post-depositional uplift of the basement high. Seismic data show that the facies thins toward the basement high but drapes over the crest and continues onto the seaward-facing flank (Fig. 2).

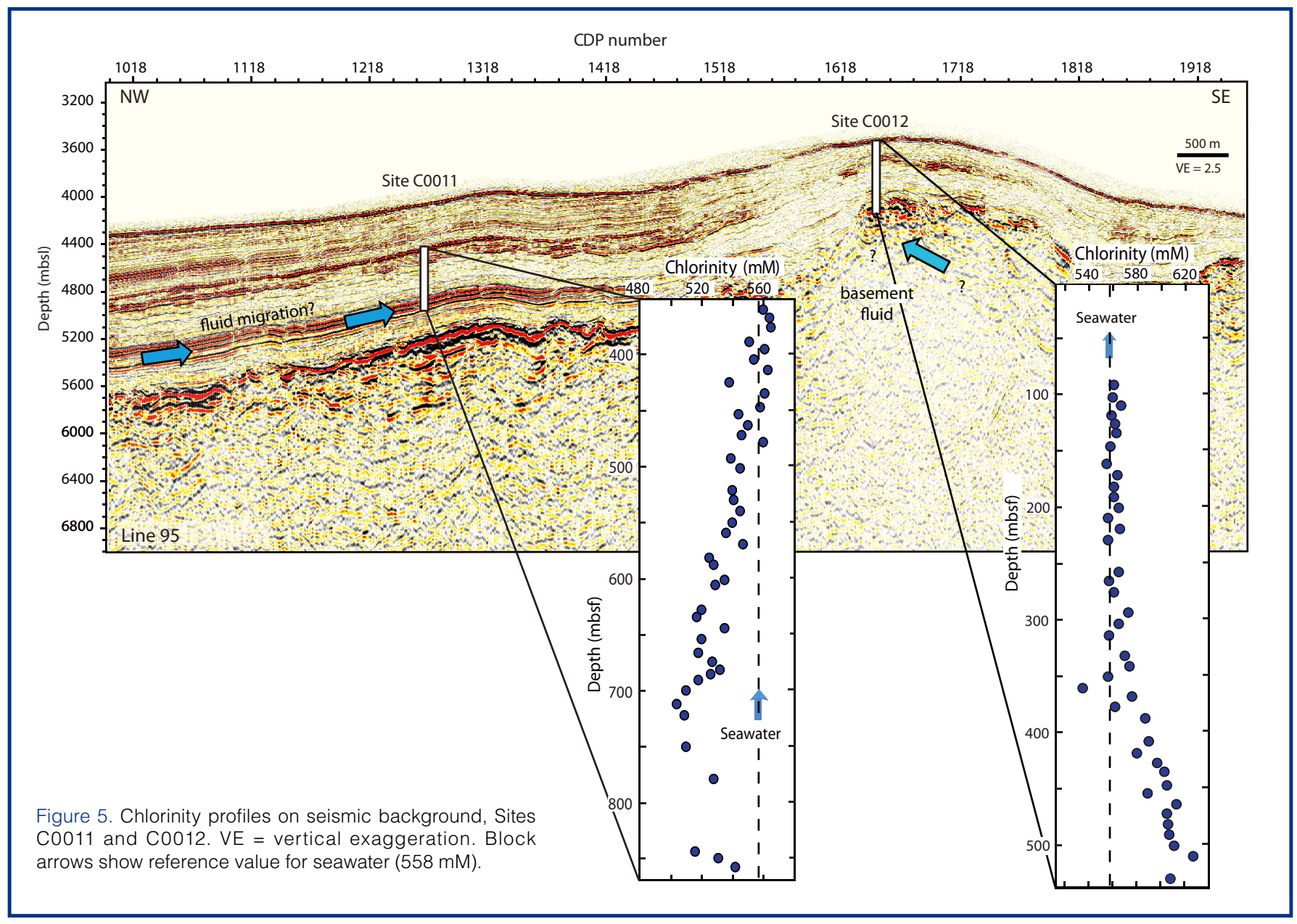


Unit III (lower Shikoku Basin hemipelagic facies) is middle Miocene (9.4 Ma to $12.7 \mathrm{Ma}$ ) in age and extends from $220 \mathrm{mbsf}$ to $332 \mathrm{mbsf}$ (Fig. 6). The lithology is dominated by bioturbated silty claystone, with scattered carbonate beds and clay-rich layers (possible bentonites). The upper portion of Unit III contains an interval with steeply inclined $\left(40^{\circ}-45^{\circ}\right)$ bedding. From seismic data, this zone of disruption appears to be associated with rotational normal faulting. We also see evidence from nannofossils of a hiatus near the top of this deformed interval (Fig. 7). Rates of hemipelagic sedimenta-tion changed at $12 \mathrm{Ma}$, although the magnitude of this shift is far more subtle than the effect at Site C0011 (Fig. 4).

Lithologic Unit IV (lower Shikoku Basin turbidite facies) is middle Miocene (12.7-13.5 Ma) in age and extends from $332 \mathrm{mbsf}$ to $416 \mathrm{mbsf}$ (Fig. 6). This interval is characterized by alternations of silty claystone, clayey siltstone, and thin, normally graded siltstone turbi-dites. Prior to drilling, we had expected this turbidite facies to pinch out against the basement high (Saito et al., 2009). The transition down-section into Unit $\mathrm{V}$ is not sharp (based on coarser-grained, volcaniclastic sandstone). These volcaniclastic-rich deposits range in age from early to middle Miocene (13.5 Ma to $\geq 18.9 \mathrm{Ma}$ ) and extend in depth from 416 mbsf to 528.5 mbsf. Unit $\mathrm{V}$ also includes beds of siltstone, siliciclastic sandstone, and tuff. Some of the sandstones display spectacular cross-laminae, plane-parallel laminae, convolute laminae, and soft-sediment sheath folds. Two detrital sources are evident for the sand grains: a volcanic terrain with fresh volcanic glass together with relatively large amounts of feldspar, and a siliciclastic source enriched in sedimentary lithic grains, quartz, and heavy minerals (including pyroxene, zircon, and amphibole). This compositional heterogeneity is reminiscent of the volcaniclastic-rich facies at ODP Site 1177 (Moore et al., 2001a). Nannofossils also provide evidence for a significant unconformity within Unit $\mathrm{V}$ at $\sim 510 \mathrm{mbsf}$; the associated hiatus spans approximately 4 m.y. (Fig. 7). This unconformity may have been caused by mass wasting during early stages of turbidite sedimentation on Kashinosaki Knoll. Additional support for this interpretation comes from the chaotic and discontinuous seismic reflectors just

Figure 6. Lithologic units and depositional ages from nannofossils data, Hole C0012A. 
below the crest of the basement high on its landwardfacing flank (Fig. 2).

We succeeded in recovering the depositional contact between pelagic claystone (Unit VI) and igneous basement (Unit VII) at a depth of 537.8 mbsf (Fig. 6). The age of Unit VI is early Miocene (>18.921 Ma, with a lower limit of $20.393 \mathrm{Ma}$ for the age-constraining nannofossil zone). These thin pelagic deposits are only $9.3 \mathrm{~m}$ thick, and they include variegated red, reddish brown, and green calcareous claystone, rich in nannofossils, with minor amounts of radiolarian spines. Carbonate content is $\sim 20 \mathrm{wt} \%$. The cored interval for the underlying basalt extends to 560.74 mbsf. Four types of lava morphology were distinguished: pillow lava, 'massive' basalt, breccia, and mixed rubble pieces caused by drilling disturbance. The basalts are aphanitic to porphyritic, and abundance of phenocrysts is highly variable, from slightly to highly phyric textures. Vesicularity is highly heterogeneous, and alteration of the basalt ranges from moderate to very high. Secondary minerals include saponite, zeolite, celadonite, pyrite, iddingsite, quartz, and calcite.

Structures in the cores from Site C0012 consist of bedding planes, minor faults, and fractures. Most of the beds dip gently to the north, and seismic data show reflectors rolling over the crest of the knoll to the south-dipping flank just seaward of the drill site (Fig. 2). Steeper bedding dips $\left(>25^{\circ}\right)$ occur only in the upper part of Unit III, within the interval of inferred block sliding.

Physical properties data reveal depth trends similar to those documented at Site C0011, with gradual downhole increases in bulk density, electrical resistivity, thermal conductivity, and P-wave velocity, and a downhole decrease in porosity. Overall, these trends are consistent with normal consolidation, although multiple forms of drilling distur- bance adversely affected data quality. Mudstone compressibility at Site C0012 is twice that interpreted for Site C0011, and there are several zones of anomalous porosity, including an interval from $\sim 100 \mathrm{mbsf}$ to 136 mbsf where changes in porosity are subdued. Porosity values are also abnormally high near the top of Unit V, these may help facilitate fluid migration at depth.

The results of interstitial water analyses from Site C0012 come as close as we can get to a true geochemical reference site for the Nankai Trough, and the problems encountered with contamination at Site C0011 are far less severe. The profile for dissolved sulfate shows quite a bit of structure, 
which is consistent with biogeochemical processes. The sulfate reduction zone is significantly deeper ( $300 \mathrm{mbsf})$ than those detected at other sites along the Nankai margin. We suspect that subdued microbial activity in the upper sections of Hole C0012A is due to lower sedimentation rates above the basement high (Fig. 7), as compared to the flanks of the Kashinosaki Knoll where terrigenous organic matter is more voluminous (Fig. 4). Dissolved hydrocarbon gases were not detected in the upper $189 \mathrm{~m}$ of sediment, but increases in dissolved methane and ethane concentrations then begin to coincide with sulfate depletion at $\sim 300$ mbsf. The hydrocarbons at Site C0012 occur in significantly lower concentrations than at Site C0011, and gases heavier than ethane were not detected. One explanation for the presence of methane and ethane is up-dip migration of gas in solution from deeper thermogenic sources. Another possibility is in situ biogenic formation from terrigenous organic matter. Regardless of their origin, sulfate concentrations at Site C0012 are probably modulated by anaerobic methane oxidation (AMO), thereby leading to the production of hydrogen sulfide. In support of this idea, we observed a marked increase in hydrogen sulfide concentration concomitant with the peak in methane concentration, and pyrite is common in the sediments over a comparable depth range.

Unlike Site C0011, values of chlorinity at Site C0012 increase by about $12 \%$ relative to seawater. Values within Units I and II are uniform $(\sim 560 \mathrm{mM})$ and begin to increase below $\sim 300$ mbsf to the maximum value of $627 \mathrm{mM}$ at 509 mbsf (Fig. 5). We suggest that this steady increase in chlorinity is a response to hydration reactions affecting dispersed volcanic ash and volcanic rock fragments (i.e., volcanic glass to smectite and zeolites) within Units IV and V. The trend of increasing chlorinity is unique with respect to other drilling sites on the Nankai trench floor and in the Shikoku Basin (including Site C0011), all of which show freshening at depth (Taira et al., 1992; Moore et al., 2001b) (Fig. 5). Regardless of the cause of freshening elsewhere, the absence of freshening at Site C0012 is important because it shows a lack of hydrogeologic connectivity between the northwest flank and the crest of the basement high. In addition, temperature-dependent alteration of volcanic ash and volcaniclastic sandstone probably controls changes in silica, potassium, and magnesium concentrations within the middle range of the sedimentary section. We attribute the documented depletion of dissolved sodium to formation of zeolites. Increases in dissolved calcium, which begin in Unit I, are probably overprinted at greater depths by deep-seated reactions in the basal pelagic claystone. The high concentrations of dissolved calcium help explain the precipitation of $\mathrm{CaCO}_{3}$ as thin layers and nodules, even at very low alkalinity $(<2 \mathrm{mM})$. In addition, all of the profiles of major cations and sulfate show reversals toward more seawater-like values within the lower half of lithologic Unit V. We tentatively attribute this shift to the presence of a seawater-like fluid migrating through the upper basaltic crust and diffusive exchange through the turbidites of lithol- ogic Unit V. The hydrology responsible for this pattern, including potential recharge and discharge zones for fluids within upper igneous basement, remains unidentified.

\section{History of Sedimentation and Fluids Around Kashinosaki Knoll}

Figure 8 shows the provisional correlation of units and unit boundaries at Sites C0011 and C0012. Recovery of the basal pelagic deposits in contact with pillow basalt at Site C0012 constitutes a major achievement. From this we know that the age of the basement is older than $18.9 \mathrm{Ma}$, but radiometric age dating will be needed to establish the eruptive age. After a brief period of pelagic settling, a long interval of mixed volcaniclastic/siliciclastic sedimentation began. The turbidite section was interrupted near the crest of Kashinosaki Knoll by a hiatus of $\sim 4$ m.y., but this is probably a consequence of local mass wasting. Deposition of the sandy to silty turbidites in the lower Shikoku Basin seems to match up with broadly coeval siliciclastic turbidites at Site 1177 (Ashizuri transect of Nankai Trough). The subsequent transition into a long period of hemipelagic sedimentation is reminiscent of a similar lithologic transition at other sites in the Shikoku Basin, but the ages are different: $\sim 7.0 \mathrm{Ma}$ to $\sim 2.5 \mathrm{Ma}$ (Site 1177) versus $\sim 12.7 \mathrm{Ma}$ to $\sim 9.1 \mathrm{Ma}$ (Sites C0011 and C0012). The middle Shikoku Basin facies (Unit II) is unique to the Kumano transect area based on its age (late Miocene) and volcanic sand content. The closest volcanic terrain at that time was probably the Izu-Bonin arc, which we interpret to be the primary source for the volcaniclastic turbidites. Sedimentation decelerated again to a regime of hemipelagic settling and air-falls of volcanic ash (upper Shikoku Basin facies) beginning at $7.8 \mathrm{Ma}$ and continuing through the Quaternary.

When viewed as a pair of sites, it is clear that the condensed section at Site C0012 displays significant reductions in unit thickness and average sedimentation rate for all parts of the stratigraphic column, relative to the expanded section at Site C0011 (Fig. 8). The basement architecture clearly modulated sedimentation rates throughout the history of the Shikoku Basin, but relief on Kashinosaki Knoll was never high enough to completely prevent the transport and deposition of sandy detritus atop the crest. This comes as something of a surprise, although comparable deposits from thick turbidity currents and/or upslope flow of gravity flows have been documented elsewhere (Muck and Underwood, 1990). This discovery is important because the basement highs of the Shikoku Basin could act as asperities once they reach seismogenic depths along the plate interface (Cloos, 1992; Bilek, 2007). The thickness, texture, and mineral composition of sedimentary strata above such subducting seamounts probably contribute to variations in friction along the fault plane.

The interactions among sedimentation, basement topography, and diagenesis set up an intriguing possibility of 
multiple fluid regimes within the Shikoku Basin (Fig. 5). We need in situ temperature constraints and refined shore-based analyses to interpret the geochemistry with greater confidence, but one regime is modulated by compaction and mineral dehydration reactions. Fluid freshening and generation of heavier hydrocarbons (ethane, propane, butane) may be occurring at greater depths (i.e., below the trench wedge or frontal accretionary prism) in concert with up-dip migration toward the Shikoku Basin through high-permeability sand-rich facies. No such freshening, however, is observed in the condensed section at Site C0012 (Fig. 5). Unlike its flanks, the crest of Kashinosaki Knoll reveals a separate pore water regime driven by in situ hydration reactions and diffusional exchange with a higher-chlorinity, more-seawater-like fluid that is migrating through the underlying igneous base- ment. In essence, that site is a bona fide pre-subduction geochemical reference site for the Nankai subduction zone, with pore fluid chemistry unaffected by diagenesis and/or focused flow closer to the prism toe. The observed increase in sulfate below $490 \mathrm{mbsf}$ is especially noteworthy; it cannot be supplied by the fluids with high concentrations of methane that exist on the deeper landward side of the seamount. Furthermore, we see an increase in hydrogen sulfide produced by AMO in the sediments above $490 \mathrm{mbsf}$, which argues for a sustained presence of sulfate below 490 mbsf. The sulfate must be replenished by active flow of methane-impoverished fluids within the highly permeable basalt below. This discovery is also very significant because it sets up the possibility of having hydrothermal circulation in the upper igneous crust (Spinelli and Wang, 2008; Fisher and Wheat, 2010) continue to modulate the hydrogeology and fluid chemistry of a subduction margin even after seamounts on the downgoing plate are subducted. This scenario of basement-hosted fluids is particularly intriguing at the seismogenic depths of the Nankai Trough, because the plate interface there is positioned at or near the top of igneous basement (Park et al., 2002).

\section{Plans for Future Drilling}

By drilling and coring two sites on the incoming Philippine Sea plate, we captured most of the fundamental compositional, geotechnical, and fluid properties of the Shikoku Basin that are likely to change down dip along the key stratigraphic intervals through which the Nankai plate boundary passes. In the future, IODP Expedition 333 will need to fill in some of the disconcerting gaps in coring and logging that remain from washed-down intervals and operational difficulties, and we must complete some much-needed measurements of borehole temperature to assess thermal history and the extent of in situ diagenesis. In the meantime, Expedition 322 will segue into a broad range of shore-based laboratory projects aimed at evaluating the many
Figure 8. Stratigraphic correlation between Sites C0011 and C0012. For Site C0011, logging-while-drilling data only from 0 mbsf to 340 mbsf. Unit boundary ages taken from integrated age-depth models (biostratigraphy and magnetostratigraphy) 
interwoven factors that collectively govern the initial, presubduction conditions. By expanding our collective knowledge of the subduction inputs, the NanTroSEIZE project will eventually be able to refine the observational and theoretical context for deep and ultra-deep riser drilling (Tobin and Kinoshita, 2006b), with the ultimate aim of understanding why transitions in fault behavior change from stable sliding to seismogenic slip (Moore and Saffer, 2001).

\section{Acknowledgements}

We are indebted to the captains, operations superintendents, offshore installation managers, shipboard personnel, laboratory officers, curators, and laboratory technicians who sailed during IODP Expedition 322 for their dedication and assistance with all aspects of logging, coring, sampling, and shipboard laboratory measurements. We also thank the Project Management Team and specialty coordinators of NanTroSEIZE for their organizational know-how and guidance with some of the scientific interpretations. Michael Strasser and two anonymous reviewers provided helpful comments to improve the manuscript.

\section{The IODP Expedition 322 Scientists}

M. Underwood (Co-Chief Scientist), S. Saito (Co-Chief Scientist), Y. Kubo (Expedition Project Manager), Y. Sanada (Logging Staff Scientist), S. Chiyonobu, C. Destrigneville, B. Dugan, P. Govil, Y. Hamada, V. Heuer, A. Hupers, M. Ikari, Y. Kitamura, S. Kutterolf, S. Labanieh, J. Moreau, H. Naruse, H. Oda, J-O. Park, K. Pickering, R. Scudder, A. Slagle, G. Spinelli, M. Torres, J. Tudge, H. Wu, T. Yamamoto, Y. Yamamoto, and X. Zhao.

\section{References}

Bilek, S., 2007. Influence of subducting topography on earthquake rupture.In Dixon, T., and Moore, J.C. (Eds.), The Seismogenic Zone of Subduction Thrust Faults: New York (Columbia Univ. Press), 123-146.

Cambray, H., Pubellier, M., Jolivet, L., and Pouclet, A., 1995. Volcanic activity recorded in deep-sea sediments and the geodynamic evolution of western Pacific island arcs. In Taylor, B., and Natland, J. (Eds.), Active Margins and Marginal Basins of the Western Pacific. AGU Geophys. Monogr., 88:97-124.

Cloos, M., 1992. Thrust-type subduction-zone earthquakes and seamount asperities: a physical model for seismic rupture. Geology, 20:601-604.

Fergusson, C.L., 2003. Provenance of Miocene-Pleistocene turbidite sands and sandstones, Nankai Trough, Ocean Drilling Program Leg 190. In Mikada, H., Moore, G.F., Taira, A., Becker, K., Moore, J.C., and Klaus, A. (Eds.), Proc. ODP, Sci. Results, 190/196: College Station, TX (Ocean Drilling Program).

Fisher, A.T., and Wheat, C.G., 2010. Seamounts as conduits for massive fluid, heat, and solute fluxes on ridge flanks. Oceanography, 23(1):74-87.
Hoffman, N.W., and Tobin, H.J., 2004. An empirical relationship between velocity and porosity for underthrust sediments in the Nankai Trough accretionary prism. In Mikada, H., Moore, G.F., Taira, A., Becker, K., Moore, J.C., and Klaus, A. (Eds.), Proc. ODP, Sci. Results, 190/196: College Station, TX (Ocean Drilling Program).

Hyndman, R.D., Yamano, M., and Oleskevich, D.A., 1997. The seismogenic zone of subduction thrust faults. Island. Arc, 6:244-260.

Ike, T., Moore, G.F., Kuramoto, S., Park, J-O., Kaneda, Y., and Taira, A., 2008a. Tectonics and sedimentation around Kashinosaki Knoll: a subducting basement high in the eastern Nankai Trough. Island Arc, 17(3):358-375. doi:10.1111/j.1440-1738. 2008.00625.x.

Ike, T., Moore, G.F., Kuramoto, S., Park, J.-O., Kaneda, Y., and Taira, A., 2008b. Variations in sediment thickness and type along the northern Philippine Sea plate at the Nankai Trough. Island Arc, 17(3):342-357. doi:10.1111/j.1440-1738.2008. 00624.x.

Kagami, H., Karig, D.E., Coulbourn, W.T., et al., 1986. Init. Repts. DSDP, 87: Washington, DC (U.S. Govt. Printing Office). doi:10.2973/dsdp.proc.87.1986.

Karig, D.E., Ingle, J.C., Jr., et al., 1975. Init. Repts. DSDP, 31: Washington, DC (U.S. Govt. Printing Office). doi:10.2973/ dsdp.proc.31.1975.

Kobayashi, K., Kasuga, S., and Okino, K., 1995. Shikoku Basin and its margins. In Taylor, B. (Ed.), Backarc Basins: Tectonics and Magmatism: New York (Plenum), 381-405.

Marsaglia, K.M., Ingersoll, R.V., and Packer, B.M., 1992. Tectonic evolution of the Japanese Islands as reflected in modal compositions of Cenozoic forearc and backarc sand and sandstone. Tectonics, 11(5):1028-1044. doi:10.1029/91TC03183.

Mikada, H., Becker, K., Moore, J.C., Klaus, A., et al., 2002. Proc. ODP, Init. Repts., 196: College Station, TX (Ocean Drilling Program). doi:10.2973/odp.proc.ir.196.2002.

Miyazaki, S., and Heki, K., 2001. Crustal velocity field of southwest Japan: subduction and arc-arc collision. J. Geophys. Res., 106(B3):4305-4326. doi:10.1029/2000JB900312.

Moore, G.F., Park, J.-O., Bangs, N.L., Gulick, S.P., Tobin, H.J., Nakamura, Y., Sato, S., Tsuji, T., Yoro, T., Tanaka, H., Uraki, S., Kido, Y., Sanada, Y., Kuramoto, S., and Taira, A., 2009. Structural and seismic stratigraphic framework of the NanTroSEIZE Stage 1 transect. In Kinoshita, M., Tobin, H., Ashi, J., Kimura, G., Lallemant, S., Screaton, E.J., Curewitz, D., Masago, H., Moe, K.T., and the Expedition 314/315/316 Scientists, Proc. IODP, 314/315/316: Washington, DC (Integrated Ocean Drilling Program Management International, Inc.). doi 10.2204/iodp.proc.314315316.102. 2009.

Moore, G.F., Taira, A., Klaus, A., et al., 2001a. Proc. ODP, Init. Repts., 190: College Station, TX (Ocean Drilling Program). doi:10.2973/odp.proc.ir.190.2001.

Moore, G.F., Taira, A., Klaus, A., Becker, L., Boeckel, B., Cragg, B.A., Dean, A., Fergusson, C.L., Henry, P., Hirano, S., Hisamitsu, T., Hunze, S., Kastner, M., Maltman, A.J., Morgan, J.K., Murakami, Y., Saffer, D.M., Sánchez-Gómez, M., Screaton, E.J., Smith, D.C., Spivack, A.J., Steurer, J., Tobin, H.J., Ujiie, 
K., Underwood, M.B., and Wilson, M., 2001b. New insights into deformation and fluid flow processes in the Nankai Trough accretionary prism: results of Ocean Drilling Program Leg 190. Geochem., Geophys., Geosyst., 2(10):1058. doi:10.1029/2001GC000166.

Moore, J.C., and Saffer, D., 2001. Updip limit of the seismogenic zone beneath the accretionary prism of southwest Japan: an effect of diagenetic to low-grade metamorphic processes and increasing effective stress. Geology, 29(2):183-186. doi:10.1130/0091-7613(2001)029<0183:ULOTSZ>2.0.CO;2.

Muck, M.T., and Underwood, M.B., 1990. Upslope flow of turbidity currents: a comparison among field observations, theory, and laboratory models. Geology, 18:54-57.

Nakajima, T., 1997. Regional metamorphic belts of the Japanese Islands. Island Arc, 6:69-90.

Okino, K., Shimakawa, Y., and Nagaoka, S., 1994. Evolution of the Shikoku Basin. J. Geomagn. Geoelectr., 46:463-479.

Park, J.-O., Tsuru, T., Kodaira, S., Cummins, P.R., and Kaneda, Y., 2002. Splay fault branching along the Nankai subduction zone. Science, 297(5584):1157-1160. doi:10.1126/science. 1074111.

Saffer, D., McNiell, L., Araki, E., Byrne, T., Eguchi, N., Toczko, S., Takahashi, K., and the Expedition 319 Scientists, 2009. NanTroSEIZE Stage 2: NanTroSEIZE riser/riserless observatory. IODP Prel. Rept., 319. doi:10.2204/iodp.pr.319.2009.

Saffer, D.M., Underwood, M.B., and McKiernan, A.W., 2008. Evaluation of factors controlling smectite transformation and fluid production in subduction zones: application to the Nankai Trough. Island Arc, 17(2):208-230. doi:10.1111/ j.1440-1738.2008.00614.x.

Saito, S., Underwood, M.B., and Kubo, Y., 2009. NanTroSEIZE Stage 2: subduction inputs. IODP Sci. Prosp., 322. doi:10.2204/ iodp.sp.322.2009

Seno, T., Stein, S., and Gripp, A.E., 1993. A model for the motion of the Philippine Sea Plate consistent with NUVEL-1 and geological data.J. Geophys. Res., 98(B10):17941-17948. doi:10.1029/ 93JB00782.

Spinelli, G.A., and Wang, K., 2008. Effects of fluid circulation in subducting crust on Nankai margin seismogenic zone temperatures. Geology, 36(11):887-890. doi:10.1130/G25145A.1.

Taira, A., Hill, I., Firth, J.V., et al., 1991. Proc. ODP, Init. Repts., 131: College Station, TX (Ocean Drilling Program). doi:10.2973/ odp.proc.ir.131.1991.

Taira, A., Hill, I., Firth, J., Berner, U., Brückmann, W., Byrne, T., Chabernaud, T., Fisher, A., Foucher, J.-P., Gamo, T., Gieskes, J., Hyndman, R., Karig, D., Kastner, M., Kato, Y., Lallement, S., Lu, R., Maltman, A., Moore, G., Moran, K., Olaffson, G., Owens, W., Pickering, K., Siena, F., Taylor, E., Underwood, M., Wilkinson, C., Yamano, M., and Zhang, J., 1992. Sediment deformation and hydrogeology of the Nankai Trough accretionary prism: synthesis of shipboard results of ODP Leg 131. Earth Planet. Sci. Lett., 109(3-4):431-450. doi:10.1016/0012821X(92)901044.

Taira, A., Tokuyama, H., and Soh, W., 1989. Accretion tectonics and evolution of Japan. In Ben-Avraham, Z. (Ed.), The Evolution of the Pacific Ocean Margins: New York (Oxford University Press), 100-123.
Taylor, B., 1992. Rifting and the volcanic-tectonic evolution of the IzuBonin-Mariana arc. In Taylor, B., Fujioka, K., et al., Proc. ODP, Sci. Results, 126: College Station, TX (Ocean Drilling Program), 627-651.

Tobin, H.J., and Kinoshita, M., 2006a. Investigations of seismogenesis at the Nankai Trough, Japan. IODP Sci. Prosp., NanTroSEIZE Stage 1. doi:10.2204/iodp.sp.nantroseize1. 2006.

Tobin, H.J., and Kinoshita, M., 2006b. NanTroSEIZE: the IODP Nankai Trough Seismogenic Zone Experiment. Sci. Drill., 2:23-27. doi:10.2204/iodp.sd.2.06.2006.

Tobin, H.J., Kinoshita, M., Ashi, J., Lallemant, S., Kimura, G., Screaton, E., Thu, M.K., Masago, H., Curewitz, D., and the Expedition 314/315/316 Scientists, 2009. NanTroSEIZE Stage 1 expeditions: introduction and synthesis of key results. Proc. IODP, 314/315/316: Washington, DC (Integrated Ocean Drilling Program Management International, Inc.). doi:10.2204/iodp.proc314315316.101. 2009.

Underwood, M.B., 2007. Sediment inputs to subduction zones: why lithostratigraphy and clay mineralogy matter. In Dixon, T., and Moore, J.C. (Eds.), The Seismogenic Zone of Subduction Thrust Faults: New York (Columbia University Press), $42-85$.

Underwood, M.B., and Fergusson, C.L., 2005. Late Cenozoic evolution of the Nankai trench-slope system: evidence from sand petrography and clay mineralogy. In Hodgson, D., and Flint, S. (Eds.), Submarine Slope Systems: Processes, Products and Prediction. Geol. Soc. Spec. Publ., 244(1):113-129. doi:10.1144/GSL.SP.2005.244.01.07.

Underwood, M.B., Saito, S., Kubo, Y., and the Expedition 322 Scientists, 2009. NanTroSEIZE Stage 2: subduction inputs. IODP Prel. Rept., 322. doi:10.2204/iodp.pr.322.2009.

Vrolijk, P., 1990. On the mechanical role of smectite in subduction zones. Geology, 18:703-707.

Yamano, M., Kinoshita, M., Goto, S., and Matsubayashi, O., 2003. Extremely high heat flow anomaly in the middle part of the Nankai Trough. Phys. Chem. Earth, 28(9-11):487-497. doi:10.1016/S1474-7065(03)00068-8.

\section{Authors}

Michael B. Underwood, Department of Geological Sciences, University of Missouri, Columbia, MO 65203, U.S.A., E-mail: UnderwoodM@missouri.edu.

Saneatsu Saito, Institute for Research on Earth Evolution, Japan Agency for Marine-Earth Science and Technology, 2-15 Natsushima-cho, Yokosuka 237-0061, Japan.

Yu'suke Kubo, Center for Deep Earth Exploration, Japan Agency for Marine-Earth Science and Technology, 3173-25 Showa-machi, Kanazawa-ku, Yokohama 236-0001, Japan. and the IODP Expedition 322 Scientists 